\title{
THE SCIENTIFIC VIEWPOINT IN STATE ISLAMIC UNIVERSITY IN INDONESIA
}

\author{
Toto Suharto
}

Faculty of Tarbiyah and Teacher Training of IAIN Surakarta

Jl. Pandawa Pucangan Kartasura Sukoharjo Surakarta 57141

Email: tosuh71@gmail.com

\section{Khuriyah}

Email: khuriyah_stainslo@yahoo.co.id

\begin{abstract}
This paper aims to reveal that this family of general (secular) scientific and religious scientific can be integrated into such a view of the epistemology of science as applied institute non-dichotomous state Islamic University or UIN. Basically is Law No. 12 in 2012 and the decision of the Director General of Islamic Education No. 3389 Year 2013 The method used is content analysis approach to the study of philosophy and Islamic education policy. The analysis showed that the Islamic colleges that have shaped the university can be in organizing educational and scientific development of both general and religious clumps. This is called the integration and interconnection (non-dichotomous) scholarly knowledge of Islam among the general sciences. Scientific form of integration is reflected in the naming of the faculty (eg. Tarbiyah and Teaching Science, Adab and Humanities, Faculty of Da'wa and Communication) and the distribution of subjects. In essence, in each course served at UIN containing core Islamic sciences, both normative and descriptive.
\end{abstract}

Keywords: Integration, Interconection, State Islamic University

\begin{abstract}
ABSTRAK
[Paper ini bertujuan mengungkap bahwa rumpun keilmuan keagamaan dan umum (sekuler) dapat diintegrasikan sedemikian rupa ke dalam sebuah pandangan epistemologi keilmuan nondikotomis lembaga sebagaimana diterapkan di state Islamic University atau UIN. Dasarnya adalab UU No. 12 tabun 2012 dan Keputusan Direktur Jenderal Pendidikan Islam No. 3389 Tabun 2013. Metode yang digunakan adalah analisis konten dengan pendekatan filsafat dan studi kebijakan pendidikan Islam. Hasil analisis menunjuk.kan bahwa perguruan tinggi agama Islam yang sudah berbentuk universitas dapat menyelenggaran pendidikan dan pengembangan baik rumpun keilmuan umum maupun keagamaan. Inilah yang disebut dengan integrasi dan interkoneksi (nondikotomis) keilmuan antara ilmu agama Islam dengan ilmu umum. Bentuk integrasi keilmuan ini tergambar dalam penamaan lembaga fakultas (contoh: Tarbiyah dan Ilmu Keguruan, Adab dan Humaniora, Fakultas Dakwah dan Komunikasi) dan sebaran mata kuliah. Intinya, dalam setiap mata kuliah yang disajikean di UIN mengandung core keilmuan Agama Islam, baik secara normatif maupun deskriptif].
\end{abstract}

Kata Kunci: Integrasi, Interkoneksi, Universitas Islam Negeri 


\section{INTRODUCTION}

The Act of Higher Education of Republic Indonesia (UU RI) s. 12. 2012 makes the status of Islamic Higher Education in Indonesia be clearly varied. There are three types of Islamic Higher Education in Indonesia, ie. UIN (State Islamic University), IAIN (State Islamic Institute) and STAIN (State Islamic College). UIN was authorized to develop both a general science and religion science, integrated and interconnected. IAIN not only can develop Islamic religious knowledge alone, but also can develop more religious faculty, while STAIN develops one type of Islam faculty only and can open some religious department (General Director Decision of Islamic Education No. 3389 in 2013).

The Article 10 paragraph 2 of The Act of Higher Education of Republic Indonesia (UU RI) s. 12. 2012 states that the branches of science and technology consist the branches of religion sciences, humanities, social sciences, natural sciences, formal sciences, and applied sciences. The explanation of the Act from article 10 paragraph (2) letter a, b, c, d, e, f states that:

Letter a:

"The branch of religion science is a branch of science which studies the beliefs of God or monotheism as well as sacred texts, among other things ushuluddin science, sharia science, adab science, dakwah science, tarbiyah science, philosophy and Islamic thought, Islamic economics, education science of Hinduism, information science of Hinduism, philosophy of Hinduism, educational science of Buddhism, information science of Buddhism, philosophy of Buddhism, education science of Christianity, education science of Catholic, theology, missiology, pastoral counseling, and science education of Kong Hu Cu".

Letter b:

"The branch of science humanities is a branch of science that examines and explores human values and human thought, including philosophy, history, linguistics, humanities, arts stage, and the science of art".

Letter c:

"The branch of social science is a branch of science that examines and explores the relationship between humans and the various phenomena of society, including sociology, psychology, anthropology, political science, archeology, regional science, humanities, economics, and geography". 
Letter d:

"The branch of natural sciences is a branch of science that examines and explores the universe other than humans, including space science, earth science, biology, chemistry, and physics".

Letter e:

The branch of formal science is a branch of science that examine and explores the theoretical formal systems, such as computer science, Letter f: logic, mathematics, statistics, and systematically.

The branch of applied science is a branch of science and technology which reviews and explore the application of science to human life such as agriculture, architecture and planning, business, education, engineering, forestry and environment, family and consumer, health, sports, journalism, mass media and communication, law, library and the museum, military, public, social workers, and transportation.

Based on the Act of Higher Education, UIN can organiz, develop and make the religion and nonreligion science as a material studies as well as technology. That is why the establishment of UIN in 2002 brought the epistemology of integration between the science of religion and nonreligion. But, nonetheless, within this epistemology, the science of religion was the basis for all scientific of State Islamic University in Indonesia (UIN).

This article intends to study the meaning of the concept of 'integration of science' that serve as the foundation of scientific epistemology of UIN. However the relation between religious knowledge and general ('seculer') knowledge, each of which needs to be explained that the autonomous status and position, especially in the implementation of the curriculum. The method used is content analysis, which is the vision and mission as well as the scientific view of such UIN discussed both by the philosophy of science and philosophy of Islamic education.

\section{DISCUSSION}

The dichotomy between secular science and religion science in Islamic world has a long, since the 14th century, since the fall of Granada, in Spain to the Christians. Since the century concentration of Muslims in learning science focus more on religion than science science of nature. Figures of the same level with Ibn Nafis (1213- 1288), Omar Khayyam (1048-1131) and Ibn al-Haytham (965-1040), which is known as a pioneer of science, not popping up anymore (Iqbal, 2007). This continues until the course of European colonialism in the Islamic countries, in the 18 th century.

In the early 18th century, movement was born that seeks the face of emerging European colonialism. The movement was known as pan- 
Islamism. One of the characters leading the way was Jamal al-Din al-Afghani (1839-1897). The movement later inspired Muhammad Abduh and Ismail alFaruki to create a new movement of 'Islamization of science'. The purpose of science is to reformulate Islamization of science to study the universe with technology applications that tend to be secular in order to return to the principles of Islam (Irawan, 2012, p. 2).

For that, the effort to "Islamize science" at above is a necessity that cannot be negotiable (Hamdi in Bagir et al, 2005, p. 182). However, it remove the dichotomous of knowledge in Islam. Islamization of science also implies that Muslims should be encouraged to own, control and develop the science to be able to contribute to the culture of the world like in the glorious day of Islam. The change of IAIN/STAIN into UIN in Indonesia, is considered as one way to remove the dichotomous that would be the one hand Muslims delivers faster mastering science and on the other hand also have faith and fear of Allah swt (Bakar, 1995, p. 234 and Mas 'ud, 2002, p. 4).

Until 2014, there were 8 UIN's in Indonesia. In this article there are four UIN will be discussed the scientific epistemology; The first UIN Syarif Hidayatullah Jakarta (established in 2002), UIN Sunan Kalidjaga Yogyakarta (established in 2004), UIN Maulana Malik Ibrahim Malang (established in 2004), and UIN Sunan Gunung Djati Bandung (established in 2005).

1. UIN Syarif Hidayatullah Jakarta: The Reintegration of Sciences

According to Azra (2000, p. 13), the idea of establishmant UIN was based on several problems encountered IAIN at that time, namely: First, IAIN did not play an optimal role in the academic, the bureaucracy and the people of Indonesia as a whole. Among these three area, it seems that role of IAIN in society is greater, because dakwah orientation is stronger than developing of science. Second, the curriculum of IAIN has not been able to rescure the science and technology in complex society. This is because the field of religious studies at IAIN, is less interaction to the secular sciences, and even still tends to be dichotomous.

From that two reasons, IAIN Jakarta adopted the concept of "IAIN with wider mandate". In this concept, education at IAIN is no longer limited to formal credentials in religious sciences whith in the humanities, but it also develop other mandates in the fields of humanities, social sciences and natural sciences. Here, the "core" of IAIN in the field of religious sciences is maintained, but at the same times formed new departments and faculties entirely. Taking into account the various constraints that exist, the importance of Islam as the core of all science, and then historical considerations, the concept of IAIN with wider mandate is chosen. Therefore, the development of IAIN Jakarta is intended not only to teach the 
Islamic sciences, but also teaches other humanities, social sciences and natural sciences (Azra, 2000, p. 16-17).

The change of IAIN's institution to be UIN formula get recommendations from government with the signing of the Joint Degree (SKB) between the Minister of National Education and Minister of Religious Affairs dated on 21 November, 2001. This was then followed up with the release of Presidential Decree No. 031 dated May 20, 2002 on Amendment of IAIN Syarif Hidayatullah Jakarta to be UIN Syarif Hidayatullah Jakarta. In response to the signing of the decree, Azra judged that "This signing marks a new history of IAIN Jakarta. We are committed to eliminate a dichotomy between secular sciences and religious sciences" (Fathurrahman, 2002, p. 323).

With a vision to be "the leading institution in developing and integrating aspects of Islamic religion, scientific, humanitarian, and Indonesian“, UIN Jakarta expands the integration agenda, namely: 1) to reintegrate sciences at the level of ontology, epistemology, and axiology, so there is no longer a dichotomy between secular sciences and religious sciences; 2) to provide the moral basis of the development of science and technology in the enlightenment of faith and piety so that it can be aligned; and 3) to articulate Islamic teachings scientifically in the context of the community life, so there is no distance between the religion values and sophistication of society (Karni, 2009, p. 309-310).

The concept of reintegration above for the first time was initiated by Azyumardi Azra. According to him, the challenges of Muslims today are: (a) the existence of separated sciences from spiritual values and ethical Islam. Sciences should be muted with religious values and spiritual, in order to bring benefits to humans; (b) the existence of marginality sciences when dealing with "religious sciences". Here, UIN just required the reconciliation and the reintegration between the two, which means returning to the transcendent unity of all science. Therefore, UIN Syarif Hidayatullah Jakarta orients itself on this model of integration, based on the beliefs, knowledge and piety, which later became the basis for the university to develop its scientific (Azra, 2005, p. 210-211).

\section{UIN Sunan Kalijaga Yogyakarta: Integration of The "Spider Web"}

The transformation of IAIN Sunan Kalijaga into UIN Sunan Kalijaga was under Presidential Decree No. 50 Year 2004 Dated on June 21, 2004. The change of institute to university launched a new paradigm in the study of religious sciences and secular sciences, namely the paradigm of integrationinterconnection that tried to integrate and connect the two kind of sciences 
that are previously dichotomy diametrically (bttp:// wnw.uin-suka.ac.id accessed on December 12, 2013).

With the vision of "Excellence and lead in the integration and the development of Islamic studies and sciences for civilization", UIN Sunan Kalijaga has the core value, which is the epistemology of integrationinterconnection. This epistemology is the idea of Amin Abdullah when he became Rector of UIN Sunan Kalijaga. According to Abdullah (2006, p. 9293), some barriers between "science" and "religion" containing its own territory in terms of object, methods of research, the criteria of truth, were very complicated. In order to make clear a relation between the seculer and religion science the integration-interconnecion paradigm seeks to reduce these tensions by trying to get a new harmony to each other.

In the epistemology of integration-interconnecion, the are three principal areas of science, i.e.: the natural sciences, social sciences and humanities, are no longer stand alone, but it will be interlinked with each other (Abdullah, 2006, p. 370). Between Hadlarat al-'Ilm, the empirical sciences in the category of science and technology, Hadlarat al-Falsafah, the rational sciences such as philosophy and culture, and Hadlärat al-Nās, the textual normative sciences such as fiqh, kalam, sufism, tafsir, hadith, philosophy, and lughah, will be integrated and connected in a scientific integration (Abdullah, 2006, p. 402-405).

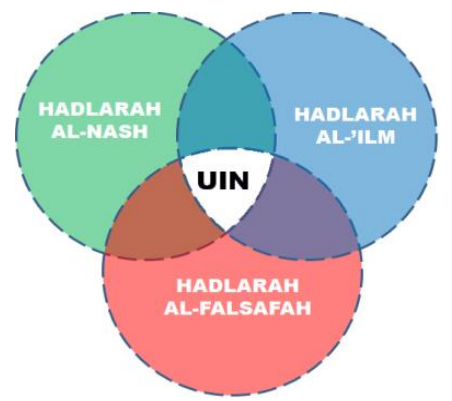

With the integration model of sciences above, the three areas of Islamic studies are integrated-interconnected. The development of three scientific areas is aim to reunite between the modern sciences and Islamic sciences in the schema of integrated-interconected paradigm, which appeared in the "Spider Web" as follows: 


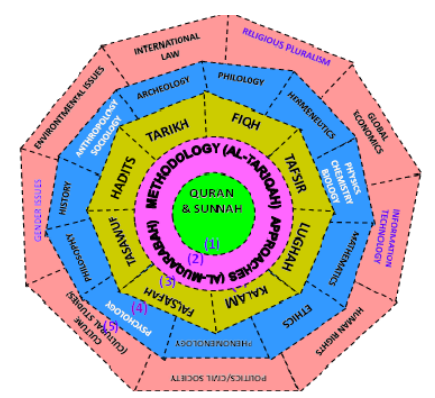

The epistemology of integration with "Spider Web" model above indicates that the scientific activity in the UIN across the country focused and limited to the track Ring One and Ring Two lines, consisting of Kalam, Philosophy, Sufism, Hadith, Tärikh, Fiqh, Tafsir, and Lughah. Whereas in the State of Islamic Institut (IAIN) and State of Islamic College (STAIN) have not been able to teach and develop on the natural social sciences and humanities as reflected in the third ring.

This does not mean that IAIN can not run the integration and interconnection of scientific concepts, but the main task not only includes a general scientific development. Insight into the integration and interconnection of knowledge is applied in IAIN and STAIN in order underlying science of religion with general scientific insights (nonreligion). Classical Islamic studies use social sciences and humanities contemporary (Abdullah, 2006, p. 107-108).

3. UIN Maulana Malik Ibrahim Malang: Integration of the "Tree of Science"

Proposed STAIN Malang to be university (UIN) was approved through Presidential Decree No.50 dated on June 21, 2004. According to the Presidential Decree, the main task of UIN Malang is to carry out a program higher education in Islamic and secular sciences. Academically, UIN Malang was developed not only knowledge derived from scientific methods such as logical reasoning through observation and experimentation, but also derived from the Qur'an and Hadith, here in after referred to as the paradigm of integration. In this paradigm, the position of the Qur'an and Hadith is very central within the framework of the scientific integration.

According to Suprayogo (bttp:// rektor.uin-malang.ac.id/ downloaded on December 10, 2013), the presence of UIN with the concept of integration is intended to eliminate the dichotomy of science. Islam is a religion, as well as science and high civilization. In fact, setbacks Muslims as a result of this dichotomy of science (Suprayogo in bttp:/ / rektor.uin-malang.ac.id/ accessed on December 10, 2013). Therefore, one of the fundamental and strategic efforts taken UIN Malang is doing the reconstruction paradigm of science, by 
putting religion as the basis of science. Finally, Suprayogo (2006, p. 57) found the format of the integration of science with the model of "Tree of Science" as follows:

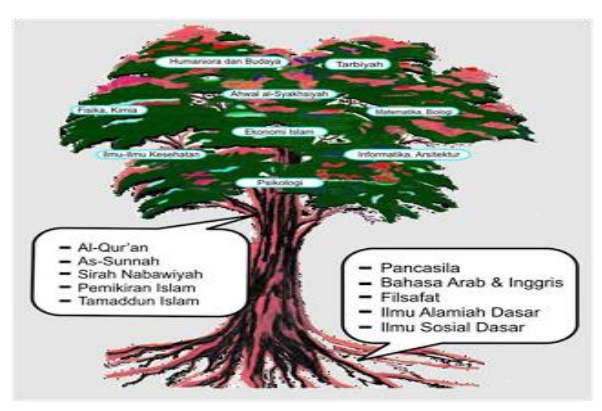

From the picture above, it is known that the scientific structure of UIN Malang is based on the universality of Islam. The metaphor used is a the solid tree, branching shady, leafy fertile and fruitful because it is supported by a strong root. The roots of the tree describe scholarly foundation of university, namely Arabic and English, philosophy, natural Sciences, social Sciences, and the Pancasila and citizenship education. Mastery of this scholarly foundation be authorized for students to understand all aspects of Islamic scholarship, which is described as the principal tree into self-identity of students of this university, namely: Qur'an and Sunnab, sirah nabawiyyah, Islamic thought, and insight of Muslim community. The branches and twigs representing the fields of science in this university are constantly growing and evolving. The lowers and fruit describe output and benefits of education process in this university, namely: faith, piety, and science.

4. UIN Sunan Gunung Djati Bandung: Integration of the "Wheel of Science"

Based on the Decree of the President of the Republic of Indonesia No. $57 / 2005$ dated October 10, 2005, the status of IAIN Bandung converted into UIN Sunan Gunung Djati Bandung. With the vision of "Being the excellence and competitive Islamic university", UIN Bandung sought: (1) organize and manage higher education professional, accountable, and competitive at national and international level, which is needed by the users of the higher education service and meet the expectations of the community; (2) conducting research and scientific studies are able to develop science, technology, and art, and able to meet the needs of communities; and (3) holding a public service that is able to develop and empower themselves to order civil society, democratic, and equitable (bttp://mmw.uinsgd.ac.id. accessed on May 2, 2014).

Natsir (2006: 32) who had initiated the integration model for UIN Bandung scientific with the "Wheel of Science" metaphor as follows: 


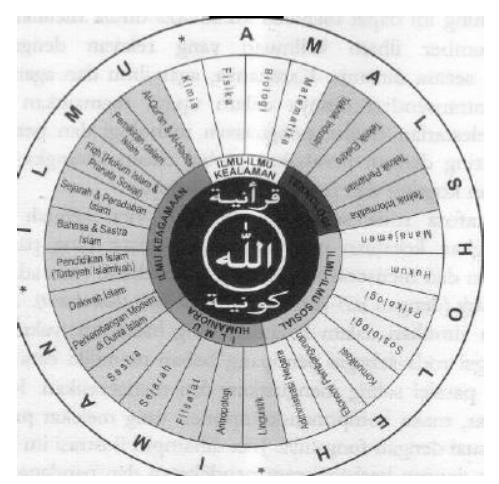

According to Natsir (2006, p. 32-43), the wheel is an essential part of a dynamic moving vehicle. Physically, a wheel that has three parts, namely the axle (shaft), section wheels (with his fingers) and the outer part of the tire (tire rubber), which can work simultaneously in a harmonious whole. Like a wheel with three parts, the UIN Bandung scientific refers to the "Philosophy Wheels" as follows:

1. The as or axis symbolizes the central point of power of the human reason that are sourced from divine values, i.e. God as the source of all sources. This central point reflects the beamed center of the values that comes from his owner; at the same time, describes the whole purpose of human endeavor. In other words, the Taubid is the foundation of development of all sciences, both from qur'aniyyah verses or kauniyyah verses.

2. The rims wheels consisting of a number of fingers, the inner circle and outer circle, symbolize the clump of science with a wide range of disciplines developed today. Although every science has its own characteristics, but it has the same function, i.e. science as a tool to understand the nature of life. The existence of differenced disciplines does not show separation that can be used as a facility of human life. The round of wheels symbolizes that every science developed at UIN Sunan Gunung Djati is always expanding horizons in scope, for the continuously evolving according to the times.

3. The outer tires symbolize the reality of life with inseparable from the spirit of divine values and passion of scientific study. The outer side of the tire, embodied three terms: faith, science and piety. This is the final target of UIN graduate profiles. The power of faith is installed through education process in situations of scientific and religious campus. The power of science is the basis of UIN Sunan Gunung Djati Bandung which reflects the dynamics of the campus as scientists struggle zone, while piety as a form of behavior that is guided by faith and science. 
The four UIN epistemologis above shows that UIN scientific has made the revealation (Qur'an and Sunnab) as a core or base for the development of science. This models was developed by the Muslims at Classical periode. In this period, any Muslim intellectual expertise, both in the fields of natural sciences, social sciences or humanities, always make the source of Islamic teachings (Qur'an and Sunnah) as the basis and core for the scientific spirit, so that the Muslim intellectualism reached its golden era, thanks to enthusiasm and encouragement of the first revelation, which has animates the life of the Muslim community at the time (Suharto and Abdullah, 2006, p. 4).

\section{Development of UIN Scientific Viewpoint}

For the academic year 2014-2015, the entire UIN in Indonesia is ready to accept new students. Under the admissions website (PMB) from the fourth UIN, study programs/majors are offered as follows:

1. UIN Syarif Hidayatullah Jakarta (bttp://akademik.uinjkt.ac.id/599/ accessed on May 2, 2014)

\begin{tabular}{|l|l|l|}
\hline No. & \multicolumn{1}{|c|}{ Faculties } & \multicolumn{1}{c|}{ Departements } \\
\hline 1. & Tarbiyah and Teacher Training & Islamic education \\
\hline & & Arabic Education \\
\hline & & $\begin{array}{l}\text { Indonesian language and Literature } \\
\text { Education }\end{array}$ \\
\hline & & English Education \\
\hline & & Social Science Education \\
\hline & & Education Management \\
\hline & & Elementary Teacher Education \\
\hline & & Kindergarten Teacher Education \\
\hline & & Biology Education \\
\hline & & Chemical Education \\
\hline 2. & Adab And Humaniora & Physic education \\
\hline & & Mathematics Education \\
\hline & & Arabic Language and Literature \\
\hline & & History and Culture of Islam \\
\hline & & Translation/Tarjamah (Arabic ) \\
\hline 3. & Ushuluddin & Library Science \\
\hline & & English Language and Literature \\
\hline & & Comparative Religion \\
\hline 4. & Sharia and Law & Aqidah dan Philosophy \\
\hline
\end{tabular}




\begin{tabular}{|c|c|c|}
\hline No. & Faculties & Departements \\
\hline & & Islamic Family Law \\
\hline & & $\begin{array}{l}\text { Criminal Law and Procedure of the } \\
\text { Islamic State }\end{array}$ \\
\hline & & Law of Islamic Economics \\
\hline & & Law Studies \\
\hline \multirow[t]{5}{*}{5.} & Dakwah and Communication & Islamic Guidance and Counseling \\
\hline & & Dakwah Management \\
\hline & & $\begin{array}{l}\text { Islamic Communications and } \\
\text { Broadcasting }\end{array}$ \\
\hline & & $\begin{array}{l}\text { Development of Islamic } \\
\text { Community }\end{array}$ \\
\hline & & Social Welfare \\
\hline 6. & Diräsah Islämiyah & Diräsah Islämiyah \\
\hline 7. & Psychology & Psychology \\
\hline \multirow[t]{5}{*}{8} & Ekonomic and Business & Management \\
\hline & & Accounting \\
\hline & & $\begin{array}{l}\text { Economics and Development } \\
\text { Studies }\end{array}$ \\
\hline & & Islamic Banking \\
\hline & & Islamic Economic \\
\hline \multirow[t]{7}{*}{9.} & Science and Technology & Agribusiness \\
\hline & & Information Systems \\
\hline & & Technical Information \\
\hline & & Mathematics \\
\hline & & Biology \\
\hline & & Chemical \\
\hline & & Physics \\
\hline \multirow[t]{4}{*}{10.} & Medicine and Health Sciences & Public Health \\
\hline & & Pharmacy \\
\hline & & Medical Education \\
\hline & & Nursing \\
\hline \multirow[t]{3}{*}{11.} & Social and Politic Studies & Sociology \\
\hline & & Politic Studies \\
\hline & & International Relations \\
\hline \multirow[t]{3}{*}{12.} & $\begin{array}{l}\text { Natural Resources and } \\
\text { Environment }\end{array}$ & Geology Engineering \\
\hline & & Petroleum Engineering \\
\hline & & Mining Engineering \\
\hline
\end{tabular}


2. UIN Sunan Kalidjaga Yogyakarta (bttp://pmb.uin-suka.ac.id/program.btml accessed on May 2, 2014)

\begin{tabular}{|c|c|c|}
\hline No. & Faculties & Departements \\
\hline \multirow[t]{4}{*}{1.} & Adab and Culture Science & Arabic Language and Literature \\
\hline & & Islamic Culture and History \\
\hline & & Library Science \\
\hline & & English Literature \\
\hline \multirow[t]{5}{*}{2.} & Dakwah and Communication & $\begin{array}{l}\text { Islamic Communications and } \\
\text { Broadcasting }\end{array}$ \\
\hline & & Islamic Guidance and Counseling \\
\hline & & $\begin{array}{l}\text { Development of Islamic } \\
\text { Community }\end{array}$ \\
\hline & & Dakwab Management \\
\hline & & Social Welfare Studies \\
\hline \multirow[t]{5}{*}{3.} & Sharia and Law & Islamic Family Law \\
\hline & & Mąhab Comparison \\
\hline & & $\begin{array}{l}\text { Constitutional Law and Political } \\
\text { Islam }\end{array}$ \\
\hline & & Islamic Civil Law and Business \\
\hline & & Law Studies \\
\hline \multirow[t]{5}{*}{4.} & Tarbiyyah and Teacher Training & Islamic Education \\
\hline & & Arabic Education \\
\hline & & Islamic Education Management \\
\hline & & Elementary Teacher Education \\
\hline & & Kindergarten Teacher Education \\
\hline \multirow[t]{4}{*}{5.} & Ushüluddin and Islamic Thought & Philosophy of Religion \\
\hline & & Comparative Religion \\
\hline & & Qur'än and Tafsìr Studies \\
\hline & & Religion Sociology \\
\hline \multirow[t]{10}{*}{6.} & Science and Technology & Mathematics \\
\hline & & Physics \\
\hline & & Chemical \\
\hline & & Biology \\
\hline & & Technical Information \\
\hline & & Industrial Engineering \\
\hline & & Mathematics Education \\
\hline & & Physics Education \\
\hline & & Chemical Education \\
\hline & & Biology Education \\
\hline 7. & Social and Humaniora & Psychology \\
\hline
\end{tabular}




\begin{tabular}{|c|c|c|}
\hline No. & Faculties & Departements \\
\hline & & Sociology \\
\hline & & Communication studies \\
\hline 8. & Islamic Bisnis and Economics & Islamic Economics \\
\hline & & Islamic Banking \\
\hline & & Islamic Finance \\
\hline
\end{tabular}

3. UIN Maulana Malik Ibrahim Malang (http://pmb.uin-malang.ac.id/programstudi/ accessed on 2 Mei, 2014)

\begin{tabular}{|c|c|c|}
\hline No. & Faculties & Departements \\
\hline \multirow[t]{6}{*}{1.} & $\begin{array}{lll}\text { Tarbiyyah and } & \text { Teacher } \\
\text { Training }\end{array}$ & Islamic Education \\
\hline & & Social Education \\
\hline & & Elementary Teacher Education \\
\hline & & Arabic Education \\
\hline & & Kindergarten Teacher Education \\
\hline & & Islamic Education Management \\
\hline \multirow[t]{2}{*}{2.} & Sharia & Islamic Family Law \\
\hline & & Islamic Bisnis Law \\
\hline \multirow[t]{2}{*}{3.} & Humaniora & Arabic Language and Literature \\
\hline & & English Language and Literature \\
\hline 4. & Psychology & Psychology \\
\hline \multirow[t]{3}{*}{5.} & Economic & Management \\
\hline & & Accounting \\
\hline & & Islamic Banking \\
\hline \multirow[t]{7}{*}{6.} & Science and Technology & Mathematics \\
\hline & & Biology \\
\hline & & Chemical \\
\hline & & Physics \\
\hline & & Technical Information \\
\hline & & Architectural engineering \\
\hline & & Pharmacy \\
\hline
\end{tabular}
4. UIN
Sunan
Gunung
Djati
Bandung

(bttp://wmw.uinsgd.ac.id/front/arsip/page/kampus/info-pmb accessed on 2 Mei, 2014)

\begin{tabular}{|l|l|l|}
\hline No. & Faculties & Departements \\
\hline 1. & Ushüluddin & Aqidah and Philosophy \\
\hline & & Comparative Religion \\
\hline & & Tafsir Hadith \\
\hline
\end{tabular}




\begin{tabular}{|c|c|c|}
\hline No. & Faculties & Departements \\
\hline & & Tasawuf and Psychoterapy \\
\hline \multirow[t]{9}{*}{2.} & $\begin{array}{l}\text { Tarbiyyah and } \text { Teacher } \\
\text { Training }\end{array}$ & Islamic Education Management \\
\hline & & Islamic Education \\
\hline & & Arabic Education \\
\hline & & English Education \\
\hline & & Mathematics Education \\
\hline & & Biology Education \\
\hline & & Physics Education \\
\hline & & Chemical Eeducation \\
\hline & & Elementary Teacher Education \\
\hline \multirow[t]{7}{*}{3.} & Sharia and Law & Judicature and Islamic Family Law \\
\hline & & $\begin{array}{l}\text { Sharia Business Law and Islamic } \\
\text { Banking }\end{array}$ \\
\hline & & State Laws and Political Islam \\
\hline & & Comparison of Mazhab and Law \\
\hline & & Legal Studies \\
\hline & & Islamic Criminal Law \\
\hline & & Islamic Financial Management \\
\hline \multirow[t]{5}{*}{4.} & Dakwah and Communications & Islamic Guidance and Counseling \\
\hline & & $\begin{array}{l}\text { Islamic Communications and } \\
\text { Broadcasting }\end{array}$ \\
\hline & & Dakwah Management \\
\hline & & Development of Islamic Community \\
\hline & & Communication Studies \\
\hline \multirow[t]{3}{*}{5.} & Adab and Humanities & History and Islamic Civilization \\
\hline & & Arabic Language and Literature \\
\hline & & English Language and Literature \\
\hline 6. & Psychology & Psychology \\
\hline \multirow[t]{7}{*}{7.} & Science and Technology & Mathematics \\
\hline & & Biology \\
\hline & & Physics \\
\hline & & Chemical \\
\hline & & Technical Information \\
\hline & & Agriculture/Agro-technology \\
\hline & & Electrical Engineering \\
\hline \multirow[t]{2}{*}{8.} & Social and Politics Studies & Sociology \\
\hline & & State Administration \\
\hline
\end{tabular}




\begin{tabular}{|l|l|l|}
\hline No. & Faculties & Departements \\
\hline & & Management \\
\hline
\end{tabular}

The faculties and departments offered by the four UINs above explain that UIN scientific has developed significantly. The significance of this development of UIN scientific is evidence that IHE mandated by the Act of Higher Education provide education in the area of study called "clump of religion science" are it has been able to "overshoot" this mandate. This "overshoot" happens because of using epistemology of integration which becomes the basis for its scientific development. The integration epistemology of UIN has been able to open up and offer a diverse faculties and departments to its students.

Thus, Article 10 paragraph 2 of the AHE mandates that IHE is authorized to conduct the study at areas called "clump of religion science", namely: (1) ushuluddin faculty; (2) sharia faculty; (3) adab faculty; (4) dakwah faculty; (5) tarbiyyah faculty; (6) faculty of philosophy and Islamic thought, and (7) faculty of Islamic economics, so the UIN scientific today has been far beyond of this seven areas. There are some UIN faculties outside the mandate of Article 10 paragraph 2 of AHE, i.e. faculty of psychology, faculty of science and technology, faculty of medicine and health sciences, faculty of social and political sciences, as well as faculty of natural resources and environment.

The existence of five faculties of UIN which is outside of the IHE studies suggests that Article 10 paragraph 2 of AHE would have not implementabled for the UIN scientific. As it is know that according to Article 5 of the Act Number 12 of 2011 on the Establishment of Legislation Regulation, ones of the principles of the formation of legislation is implementable. In this context, the Article 10 paragraph 2 of AHE is not enough implementable for the UIN scientific.

The success of UIN in developing its scientific is based on epistemology of integration that is sourced from the universality of Islam. According to Kartanegara (2006, p. 119), the Qur'an is the main book of science, in which no one misses anything. Everything has been covered in the Qur'an, both of which regulate the human relationship with God, man's relationship with his fellow man, or man's relationship with the nature and the environment. Achmad Baiquni (1997, p. 17) asserts that: "Actually, all human knowledges are available in the Qur'an". Thus, the Qur'an can be a source of inspiration for the birth of a variety of sciences, both social sciences, cultural sciences and humanities, natural sciences, especially the religious sciences. In the Qur'an, many verses found that inspired the development of UIN scientific (Suharto and Suparmin, 2014, p. 64-114). 
This is the meaning of the integration of UIN scientific in Indonesian derived from the revelation.

\section{CONCLUSION}

Based on the above explanation, this paper can be summarized in the following points; First, the Act Number 12/2012 on Higher Education, has been the constitutional basis for the implementation of UIN in Indonesia, namely by integrating between religion science and secular science as part of a the branches of science and technology. There are seven areas mandated for UIN to conducted its education, namely: 1) Ushüluddin and Philosophy Faculty; 2) Sharia and Law Faculty; 3) Adab and Humaniora Faculty; 4) Dakwah and Comunication Faculty; 5) Tarbiyyah and Instructional Teaching Faculty; 6) Faculty of Philosophy and Islamic Thought; 7) Faculty of Islamic Economics; 8) Science and Technology; 9) Healts and Medcine Science; 10) Psychology Faculty; 11) Social and Politic Faculty; and Faculty of Natural Resources and Environment. Second, the birth of UIN in Indonesia since 2002, is more driven to eliminate the dichotomy between religion and science. The UIN has developed the epistemology of integration, as seen in four cases of UIN. Third, based on the epistemology of integration, UIN has offered faculties and departments in diverse. In developing and implementing the scientific viepoint of integration, UIN is based on the nature of the universality of the teachings of Islam, namely, that all knowledges belong to Allah swt. Therefore all knowledges are required to be studied seriously and practiced as possible for the welfare of mankind and nature.

\section{BIBLIOGRAPHY}

Abdullah, M. Amin. (2006). Islamic Studies di Perguruan Tinggi: Pendekatan Integratif-Interkonektif. Yogyakarta: Pustaka Pelajar.

Azra, Azyumardi. (2000). "IAIN di Tengah Paradigma Baru Perguruan Tinggi" in Komaruddin Hidayat and Hendro Prasetyo, Problem dan Prospek LAIN: Antologi Pendidikan Tinggi Islam. Jakarta: Dirjen Binbaga Islam.

Azra, Azyumardi. (2005). "Reintegrasi Ilmu-Ilmu dalam Islam" in Zainal

Abidin Bagir dkk. (eds.), Integrasi Ilmu dan Agama: Interpretasi dan Aksi. Bandung: Mizan.

Bagir, A.Z, et al. editor. (2005). Integrasi Ilmu dan Agama, Bandung: Mizan.

Baiquni, Achmad. (1997). Al-Qur'an dan Ilmu Pengetabuan Kealaman.

Yogyakarta: Dana Bakhti Prima Yasa.

Bakar, Osman, (1995). Taubid Dan Sains. Jakarta: Pustaka Hidayah.

Fathurrahman, Oman. (2002). "Prof. Dr. Azyumardi Azra, M.A.: 
Mewujudkan 'Mimpi' IAIN menjadi UIN" in Badri Yatim dan Hamid Nasuhi (eds.), Membangun Pusat Keunggulan Studi Islam. Jakarta: IAIN Jakarta Press.

http://akademik.uinjkt.ac.id/599/ accessed on Mei 2, 2014.

http://pmb.uin-malang.ac.id/program-studi/ accessed on Mei 2, 2014.

http://pmb.uin-suka.ac.id/program.html accessed on Mei 2, 2014.

http://rektor.uin-malang.ac.id/ accessed on Desember 10, 2013.

http://uin-malang.ac.id accessed on Desember 10, 2013.

http://www.uinsgd.ac.id/front/arsip/page/kampus/info-pmb accessed on Mei 2, 2014.

http://www.uin-suka.ac.id accessed on Desember 12, 2013.

Idi, Abdullah and Toto Suharto. (2006) Revitalisasi Pendidikan Islam. Yogyakarta: Tiara Wacana.

Irawan, (2012). Manajemen Perubahan (Strategis) Budaya Organisasi Pendidikan Tinggi Islam Negeri (Unpublished doctoral thesis). Universitas Islam Nusantara, Indonesia.

Iqbal, Muzaffar, (2007). Science and Islam. London: Greenwood Press.

Karni, Asrori S. (2009). Etos Studi Kaum Santri: Wajah Baru Pendidikan Islam. Bandung: Mizan.

Kartanegara, Mulyadhi. (2006). Reaktualisasi Tradisi Ilmiah Islam. Jakarta: Baitul Ihsan.

Mahkamah Konstitusi. (2010). Membangun Demokrasi Substantif, Menegubkan Integritas Institusi: Laporan Tahunan 2010. Jakarta: Sekretariat Jenderal dan Kepaniteraan Mahkamah Konstitusi.

Natsir, Nanat, Fatah. (2006). "Merumuskan Landasan Epistemologi Pengintegrasian Ilmu Qur'aniyyah dan Kawniyyah" in Tim Editor, Pandangan Keilmuan UIN: Wabyu Memandu Ilmu. Bandung: Gunung Djati Press.

Panja RUU Pendidikan Tinggi Komisi X DPR RI. (2012). "Kerangka Acuan Kunjungan Kerja Panja Komisi X DPR RI dalam Rangka Masukan terhadap RUU tentang Pendidikan Tinggi ke Universitas Hasanuddin, Universitas Brawijaya dan Universitas Lambung Mangkurat".

RUU Pendidikan Tinggi Hasil Panja 04 April 2012.

Suharto, Toto and Suparmin. (2014). Ayat-Ayat al-Qur'an tentang Rumpun Ilmu Agama: Perspektif Epistemologi Integrasi-Interkoneksi. Sukoharjo: FATABA Press.

Suprayogo, Imam. (2006). Paradigma Pengembangan Keilmuan Islam Perspektif UIN Malang, Malang: UIN-Malang Press.

Undang-Undang RI No. 12 Tahun 2011 tentang Pembentukan Peraturan PerundangUndangan.

Undang-Undang RI No. 12 Tabun 2012 tentang Pendidikan Tinggi. 